\title{
Formation of Intermetallics Layers in Ni-Ti System Prepared by Direct Energy Deposition
}

\author{
Pavel Salvetr ${ }^{1}$, Jaroslav Vavř́k ${ }^{1}$, Andrea Školáková ${ }^{2}$, Pavel Novák ${ }^{2}$ \\ ${ }^{1}$ COMTES FHT, Prumyslova 995, 33441 Dobrany. Czech Republic. E-mail: pavel.salvetr@comtesfht.cz, jaroslav.va- \\ vrik@comtesfht.cz \\ ${ }^{2}$ University of Chemistry and Technology, Department of Metals and Corrosion Engineering, Technicka 5, 16628 Prague \\ 6, Czech Republic. E-mail: skolakoa@vscht.cz, panovak@vscht.cz
}

The Ni-Ti alloys with approximately equiatomic chemical composition are one of the most important materials from the shape memory alloys. Excellent properties such as shape memory effect and superelasticity are based on the phase transformation between austenite and martensite structure of the NiTi phase. In the past the investigation of the preparation methods was focused on melting metallurgy - vacuum induction melting and arc re-melting and powder metallurgy routes like self-propagating high-temperature synthesis, hot isostatic pressing and spark plasma sintering. In the last several years importance of the additive manufacturing has increased significantly. This paper deals with formation of the $\mathrm{Ni}$-Ti intermetallic phases between the nickel and titanium layers deposited on each other by direct energy deposition energy method. The varied mixture of the $\mathrm{Ti}_{2} \mathrm{Ni}$, $\mathrm{NiTi}$ and $\mathrm{Ni}_{3} \mathrm{Ti}$ phases was formed in agreement with the binary $\mathrm{Ni}$-Ti phase diagram. Some problems like cracking and nickel loss have to be solved by preheating of platform or adjustment of laser parameters.

Keywords: Ni-Ti alloys, Additive manufacturing, Direct energy deposition

\section{Introduction}

The Ni-Ti shape memory alloys belong to a group of materials with extraordinary properties such as shape memory effect and superelasticity. Apart from the shape memory effect and superelasticity, these alloys are distinguished by good mechanical properties and high corrosion resistence. The shape memory effect occur in the $\mathrm{Ni}$ $\mathrm{Ti}$ alloys due to the difusionless, solid state, reversible phase transformation between austenite - high-temperature (cubic) and martensite - low-temperature (moniclinic) structure. The shape memory effect and temperatures of the phase transformation depend on chemical composition and impurities in the Ni-Ti alloys extensively [1]. The carbon and oxygen belong to the main impurities. Especially carbon can get into the alloy during production by conventional melting process such as vacuum induction melting (VIM), which is the most often used way of industrially production. Carbon reacts with titanium and creates carbide inclusions during solidification [2]. Titanium brings high affinity to oxygen in the Ni-Ti alloys. The solubility of oxygen in the NiTi phase is low in contrary to the $\mathrm{Ti}_{2} \mathrm{Ni}$ phase. $\mathrm{The}^{\mathrm{Ti}}{ }_{2} \mathrm{Ni}$ phase is saturated by oxygen acording to the equation (1) until the the oxide phase $\mathrm{Ti}_{4} \mathrm{Ni}_{2} \mathrm{O}$ is formed $[3,4]$.

$$
2 \mathrm{Ti}_{2} \mathrm{Ni}+\frac{1}{2} \mathrm{O}_{2} \rightarrow \mathrm{Ti}_{4} \mathrm{Ni}_{2} \mathrm{O}
$$

Moreover, all changes in nickel - titanium ratio (including formation $\mathrm{Ni}$ - and $\mathrm{Ti}$-rich phases or carbides and oxide particles) significantly influence the temperatures of the phase transformation. It is stated in [5] that an increase in the content of nickel by 0.1 at. \% may cause the decreace of the transformation temperature up to $10{ }^{\circ} \mathrm{C}$. In case of the use of additive manufacturing as production method for the Ni-Ti alloys, the contamination of carbon from melting crucible like in VIM is excluded and the content of oxygen is limited using the protective athmosphere (vacuum, argon) in the chamber.
Additive manufacturing methods are very attractive because they can fabricate samples directly with the varied or near-net shaped component with minimal or without machining operations and it is very useful in case of alloys with poor machinabilty. Additive manufacturing techniques enable to prepare wide spectrum of metallic material (for example stainless, maraging and tool steels, titanium, magnesium, aluminium and nickel based alloys [6-10]. Thus the widespread usage of additive manufacturing is expected in aerospace and automotive industry, biomaterials and implants with various sizes and shapes of pores. This porosity is desired to good cells addhesion and in-grow of bone cell or to approach mechanical properties of the bone and the implant. The porous structure can be obtained by various powder metalurgy methods as conventional sintering (CS), hot isostatic pressure (HIP) or self-propagating high-temperature synthesis (SHS) [11-14]. The main advantage of additive technology against these methods represent a possibility of adjustment of porosity approximately at the range 0-90 \% and to design pore parameters as shape, connectivity and distribution. The architecture and geometrical information of the samples are created according the desired CAD model [11].

The additive manufacturing techniques of the Ni-Ti alloys can be divided in two groups - powder bed fusion based technologies and flow based deposition techniques termed as direct energy deposition (DED) too. The powder bed technique deal with the deposition of the powder through a roller, blade or knife, powder is compacted and dispersed across a deposition platform and powder is selectively melted or sintered in a prescribed path at each hiegh by energy source (laser, electron beam) [15, 16]. Selective laser melting (SLM), selective laser sintering (SLS), direct metal laser sintering (DMLS) or electron beam melting (EBM) belong to powder bed methods. The prealloyed Ni-Ti powders are usually used in powder bed as input raw material. Whereas the flow based deposition 
method used rather elemental nickel and titanium powders, which are deposited through one or more nozzles in the desired chemical composition. The injected stream of powder is scanned by laser simultaneously. There are two ways of the process - in the first way, the focusing lens and nozzles are staying in one position while the XY table moves according to the CAD information. On the contrary, in the second way - the platform is stationary while the focusing lens and nozzle shift based on CAD data. In both methods, the focused lens and nozzle move up after completion of the previous layer. The flow based methods involve techniques named Laser Engineering Net Shapping (LENS), Direct Light Fabrication (DLF) [15]. The schematic illustration and differences between flow based and powder bed techniques are shown and described at work [17].

This paper brings results of preparation of the Ni-Ti alloys by additive manufacturing particularly direct energy method (DED). Individual nickel and titanium layers deposited each other and three various chemical compositions (approx. equiatomic, titanium- and nickel-rich) were fabricated to observed and compared microstructures, porosity and phase compositions with other preparation routes and binary phase diagram.

\section{Materials and methods}

A gas-atomized nickel powder (Sandvik Osprey LTD) and plasma-atomized titanium powder (AP\&C) with mean particle size $45-150 \mu \mathrm{m}$ were used for purpose of additive manufacturing by direct energy deposition. Spherical particles of powders are shown at Fig. 1. DED builds (cubes with size 10x10x10 mm) were performed in argon protective atmosphere using InssTek MX-600 machine with $2 \mathrm{~kW}$ Ytterbium fiber laser.
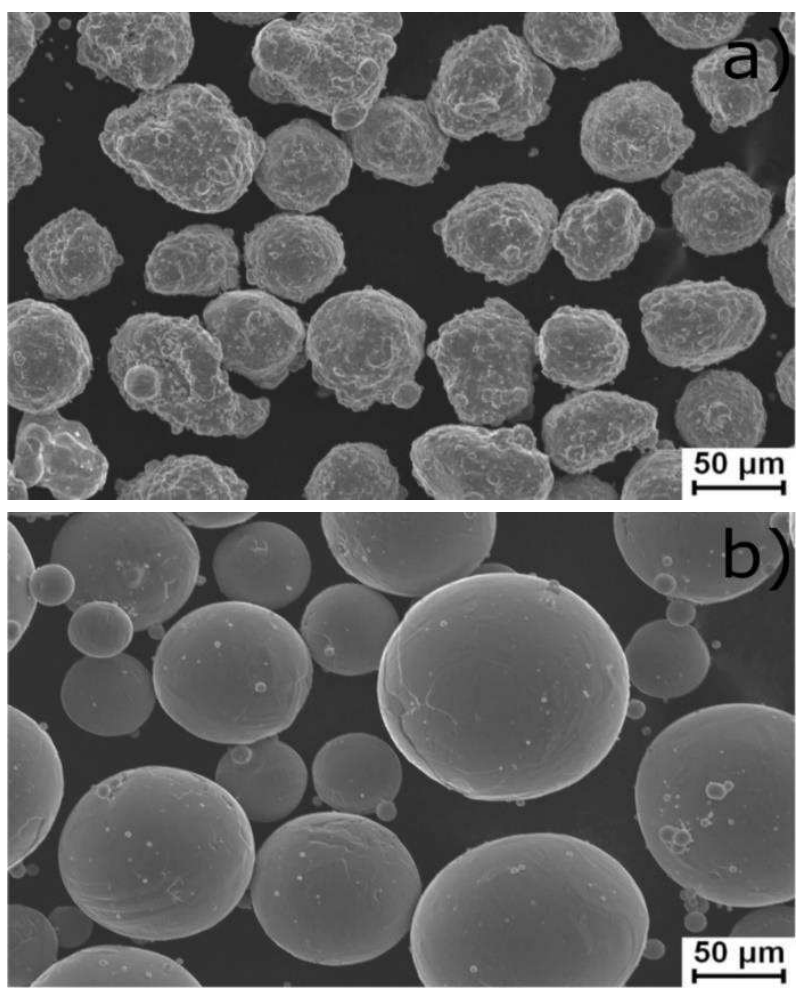

Fig. 1 Input powders prepared by atomization: a) nickel, b) titanium
Firstly, the separate nickel and titanium layers were built to observe a formation of the individual intermetallics phases at interface. Then the nickel and titanium layers with the width of $1 \mathrm{~mm}$ were deposited and finally the $\mathrm{Ti}$ and Ni powder feed rates were set in ranges to achieve the chemical compositions near the $\mathrm{Ni}_{3} \mathrm{Ti}$ phase $-\mathrm{Ni}$-Ti26 wt. \% to study the possibility of loss of nickel form the alloy due to evaporation during laser heating. The parameters used during direct energy deposition are following.

- Laser power400 - $500 \mathrm{~W}$

- Laser scanning speed $14 \mathrm{~mm} / \mathrm{s}$

- Layer thickness0.25 mm

- Laser beam spot size $0.8 \mathrm{~mm}$

- $\quad$ Ni powder feed rate $1.8 \mathrm{~g} / \mathrm{min}$

- Ti powder feed rate $0.6 \mathrm{~g} / \mathrm{min}$

- Hatch spacing0.5 mm

- $\quad \mathrm{Ni}$ carrier gas (flow rate) $2.5 \mathrm{l} / \mathrm{min}$

- Ti carrier gas (flow rate)3.0 1/min

- Shielding gas (flow rate) $10.0 \mathrm{l} / \mathrm{min}$

The metallographic samples were prepared on the cut parallel with the direction of built. The microstructure of the samples was revealed by etching in Kroll's reagent ( $10 \mathrm{ml} \mathrm{HF}, 5 \mathrm{ml} \mathrm{HNO}_{3}$ and $85 \mathrm{ml} \mathrm{H}_{2} \mathrm{O}$ ). The microstructure was observed by light microscope Nikon ECLIPSE MA200 and scanning electron microscope JEOL IT 500 HR equipped with the EDS analyser Octane Elite Super for identification of chemical composition of individual phases. The phase composition of alloys was identified on ground surfaces of the samples using X-ray diffraction (XRD) PANalytical X'Pert Pro diffractometer with a copper anode. The area fraction of the $\mathrm{Ni}_{3} \mathrm{Ti}$ phase was evaluated by NIS Elements 5.2 image analysis software.

\section{Results and discussion}

The titanium layer was built on nickel layer by direct energy deposition method in order to observe a formation of the Ni-Ti intermetallics phases. As it is visible at Fig. 2 the large crack was formed between both layers. The distance between both parts is approximately $90 \mu \mathrm{m}$. The reason for the crack between nickel and titanium parts is probably high cooling rate, difference in thermal expansion and conductivity of nickel and titanium, which lead to the occurence of the internal stress. The more detailed observation by scanning electron microscope found out the layers of the intermetallics phases on the edges of both parts and it was found out that the crack is going mainly across the $\mathrm{Ti}_{2} \mathrm{Ni}$ phase or along the interface between the $\mathrm{Ti}_{2} \mathrm{Ni}$ and NiTi phases (Fig. 3). The chemical composition of individual areas is summarized in Tab. 1. In the direction to nickel layer, the $\mathrm{Ti}_{2} \mathrm{Ni}$ phase passes to $\mathrm{NiTi}$ phase, the titanium content decreases little by little. On the edge of the NiTi phase, the $\mathrm{Ni}_{3} \mathrm{Ti}$ phase was formed which is changed to the nickel layer. In direction to nickel there are two noticeable boundaries between phases the $\mathrm{Ti}_{2} \mathrm{Ni} / \mathrm{NiTi}$ phases and $\mathrm{NiTi} / \mathrm{Ni}_{3} \mathrm{Ti} / \mathrm{Ni}$ phase. On the contrary, the nickel content decreases and the amount of titanium increases in the phase mixture with the $\mathrm{Ti}_{2} \mathrm{Ni}$ phase until the microstructure is created only by titanium, see at Fig. 3. 


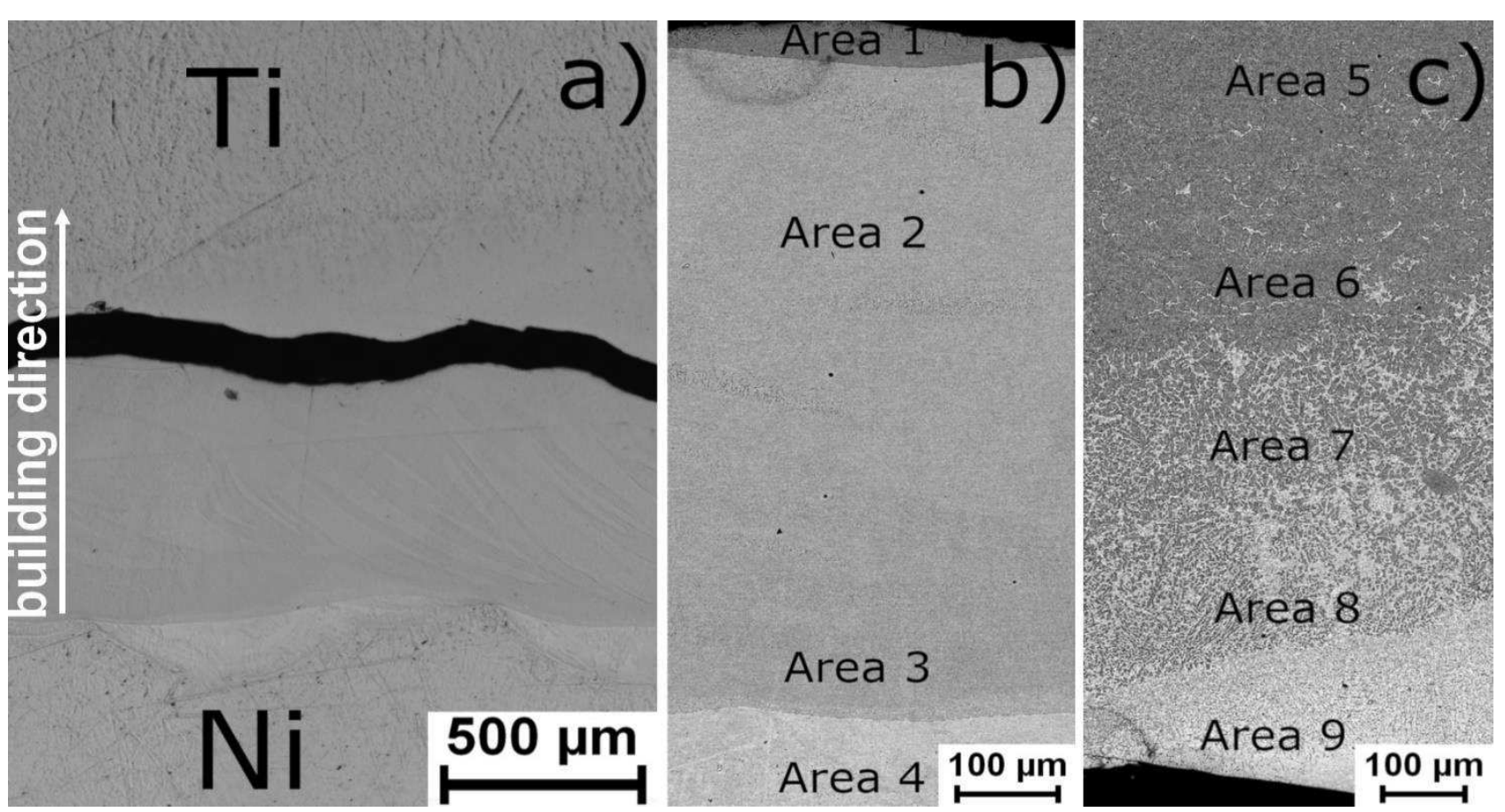

Fig. 2 a) crack between Ni and Ti layer - unetched state - light microscope, etched state - SEM-BSE b) microstructure in direction to $\mathrm{Ni}, \mathrm{c}$ ) microstructure in direction to $\mathrm{Ti}$
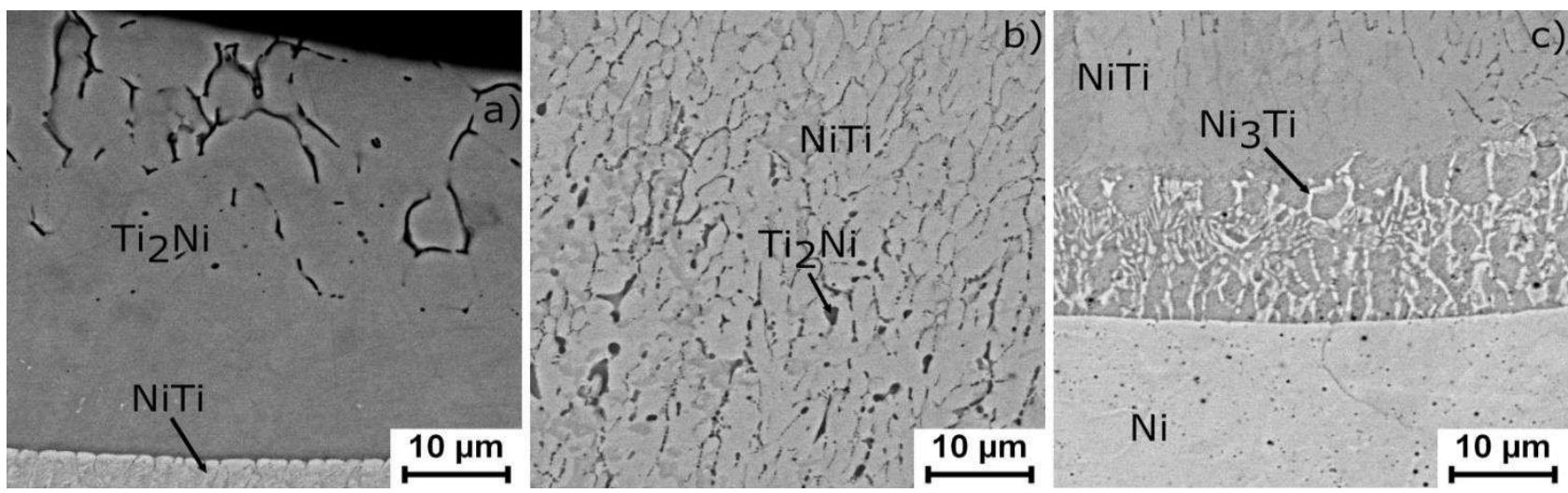

Fig. 3 Microstructure of a) Area 1/2, b) Area 2, c) Area 3/4

Tab. 1 Chemical compositions of individual areas

\begin{tabular}{ccc}
\hline Wt. \% & Ni & Ti \\
\hline Area 1 & 34.2 & 65.8 \\
Area 2 & 50.8 & 49.2 \\
Area 3 & 53.3 & 46.7 \\
Area 4 & 100.0 & 0.0 \\
Area 5 & 4.5 & 95.5 \\
Area 6 & 10.1 & 89.9 \\
Area 7 & 16.5 & 83.5 \\
Area 8 & 21.2 & 78.8 \\
Area 9 & 34.1 & 65.9 \\
\hline
\end{tabular}

When the titanium and nickel layers were deposited on each other with thickness of $1 \mathrm{~mm}$, the larger crack between layer did not create and the diffusion process occurred in a wide range and the intermetallic phases are formed. Fig. 4 with the EDS map of chemical composition represents the transition $\mathrm{Ni} / \mathrm{Ti} / \mathrm{Ni}$ rich areas. In the nickel rich side there is predominantly the $\mathrm{Ni}_{3} \mathrm{Ti}$ phase with some amount of the NiTi phase and a low amount of the $\mathrm{Ti}_{2} \mathrm{Ni}$ phase (area a). This mixture transforms into the $\mathrm{Ni}_{3} \mathrm{Ti}-\mathrm{NiTi}$ phase rich layer, the fraction of the $\mathrm{Ni}_{3} \mathrm{Ti}$ phase decreases whereas the $\mathrm{Ti}_{2} \mathrm{Ni}$ increases with increasing content of titanium - closer to the titanium rich layer (area $b$ ). The microstructure of the original titanium area is composed of $\mathrm{Ti}_{2} \mathrm{Ni}$ matrix with islets of the NiTi phase (area c). The changeover to nickel rich area is equal again - the $\mathrm{Ti}_{2} \mathrm{Ni}$ and NiTi phases are converted to the NiTi$\mathrm{Ni}_{3} \mathrm{Ti}$ phase mixture with the increasing fraction on the nickel rich phase. Moreover some areas with the fine particles of the $\mathrm{Ni}_{4} \mathrm{Ti}_{3}$ phase (area d) with similar morphology like in previous studies [18] were observed frequently at the $\mathrm{Ti} / \mathrm{Ni}$ interface than at $\mathrm{Ni} / \mathrm{Ti}$ interface. Detail of these particles and microstructures of other labelled areas you can see at Fig. 5. The Ni-rich area is prone to cracking in the parallel direction to the building direction. The crack looks like in the Ni-Ti30 sample at Fig. 7. The reason for cracking is probably in high cooling rate, which leads to the induction of the internal stress. 

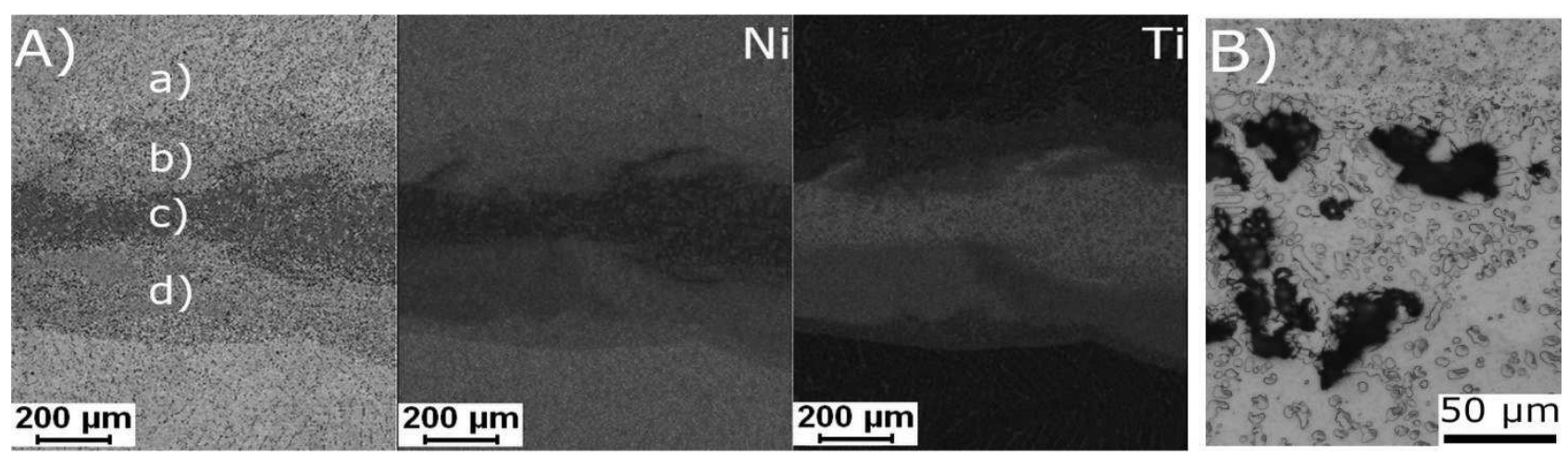

Fig. 4 A) EDS map of chemical composition Ni/Ti/Ni layers with selected areas for microstructure observation, B) Porosity formed in the $\mathrm{Ti}_{2} \mathrm{Ni}$ rich layer

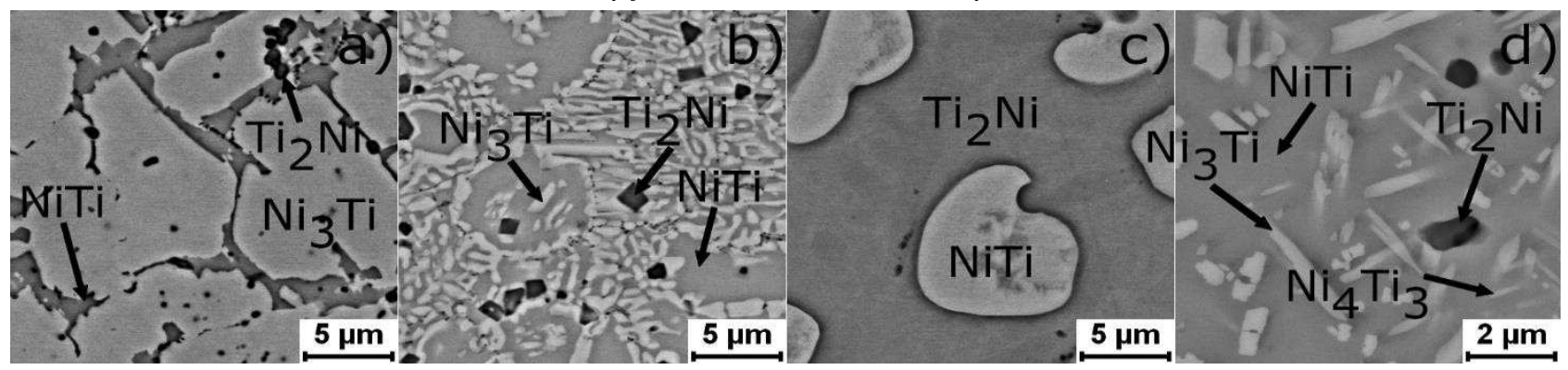

Fig. 5 Microstructures of the selected areas from EDS map a) area with composition NiTi27, b) NiTi37, c) NiTi61 and d) $\operatorname{NiTi46}(w t . \%)$

The growth of the Ni-Ti intermetallics was investigated previous during heating and reactive sintering of the powder mixture (nickel and titanium elemental powders) and by heating of titanium bulk covered by nickel. The reaction mechanism between nickel and titanium and the ignition temperature of reaction were researched in the Ni-Ti45.4 (wt. \%) powder mixture at the temperatures of 850 and $950{ }^{\circ} \mathrm{C}$ for various duration. At both temperatures, the growth of the $\mathrm{Ti}_{2} \mathrm{Ni}, \mathrm{NiTi}$ and $\mathrm{Ni}_{3} \mathrm{Ti}$ phases occurred at the contact points of pure $\mathrm{Ni}$ and $\mathrm{Ti}$ powders. The higher sintering temperature and longer sintering time provided the microstructures with a high content of the intermetallic phases whereas nickel and titatanium regions wane. Two types of experiments were carried out $[19,20]$. At the same time the porosity develops at the temperatures of $850{ }^{\circ} \mathrm{C}$ and $950{ }^{\circ} \mathrm{C}$ and it is increasing with longer sintering time. In the microstructure, there are two types of pores. The circular or ring pores close to the nickel particles are developed at $850{ }^{\circ} \mathrm{C}$. These pores corresponding to the layer of the $\mathrm{Ni}_{3} \mathrm{Ti}$ phase. At $850{ }^{\circ} \mathrm{C}$ solid-state sintering occurs and an unbalanced mass flux and different diffusion rates of $\mathrm{Ni}$ and $\mathrm{Ti}$ lead to Kirkendall porosity [21]. The Kirkendall porosity development in the $\mathrm{Ni}_{3} \mathrm{Ti}$ phase regions was observed by sintering at lower temperature of $650{ }^{\circ} \mathrm{C}$ and long duration too. This investigation was carried out at the Ni-Ti diffusion couple consisting of titanium bulk sample coated by nickel [22]. Another porosity in the Ti-rich areas was formed at $950{ }^{\circ} \mathrm{C}$ commonly with Kirkendall porosity. It is caused probably due to melting of Ti rich areas according to the eutectic melting reaction (Eq. 2) at $942{ }^{\circ} \mathrm{C}$ [20]. By this way porosity could be formed in the titanium rich areas at Fig. 3 or at Fig. 4 where porosity is aligned in the row along the titanium layer (perpendicular to the building direction).

$$
\beta-T i+T i_{2} N i \rightarrow \mathrm{L}
$$

The chemical composition of the Ni-Ti26 (wt. \%) alloy was determined by the EDS analysis with the following result - Ni70-Ti30 (wt. \%). It means that there is a difference in the chemical composition about approximately $4 \mathrm{wt}$. $\%$. The relatively low temperature of nickel evaporation $\left(2732{ }^{\circ} \mathrm{C}\right)$ compared to titanium $\left(3287^{\circ} \mathrm{C}\right)$ can cause this change of chemical composition during laser processing. It is necessary to consider this effect by reach of the desired transformation temperatures of laser fabricated product [23]. The microstructure of Ni-Ti30 wt. \% sample consists mainly of the $\mathrm{NiTi}$ and $\mathrm{Ni}_{3} \mathrm{Ti}$ phases and very small amount of the $\mathrm{Ti}_{2} \mathrm{Ni}$ phase. This phase composition was confirmed by XRD analysis which result is shown at Fig. 6. The melt pool after laser deposition and the crack parallel with the building direction are visible at Fig. 7 taken by the light microscope whereas small particles of the $\mathrm{Ti}_{2} \mathrm{Ni}$ phase were observed by the scanning electron microscope. Results of the EDS analysis for phases are placed in Tab. 2 . The $\mathrm{Ni}_{3} \mathrm{Ti}$ phase extends $68 \pm 2.9 \%$ of area fraction. The phase composition and the shape of phases are in a good agreement with a similar alloy prepared by reactive sintering [24]. The cracks in the Ni-Ti30 sample can be caused by high cooling rate, which has various values in the middle and in the side of specimen which leads to appearance of internal stress again.

The results of our first experiments show the possibility of preparation intermetallics from the Ni-Ti system by additive manufacturing - direct energy deposition (DED). There are two points to solve them. Firstly, it is necessary 
to prevent the formation of cracks. The solution and reduction of cracks can be supported for example by preheating of the platform. The second difficulty can be evaporation of nickel. It is necessary to work with it and to adjust the Ni:Ti ratio in the powder mixture.

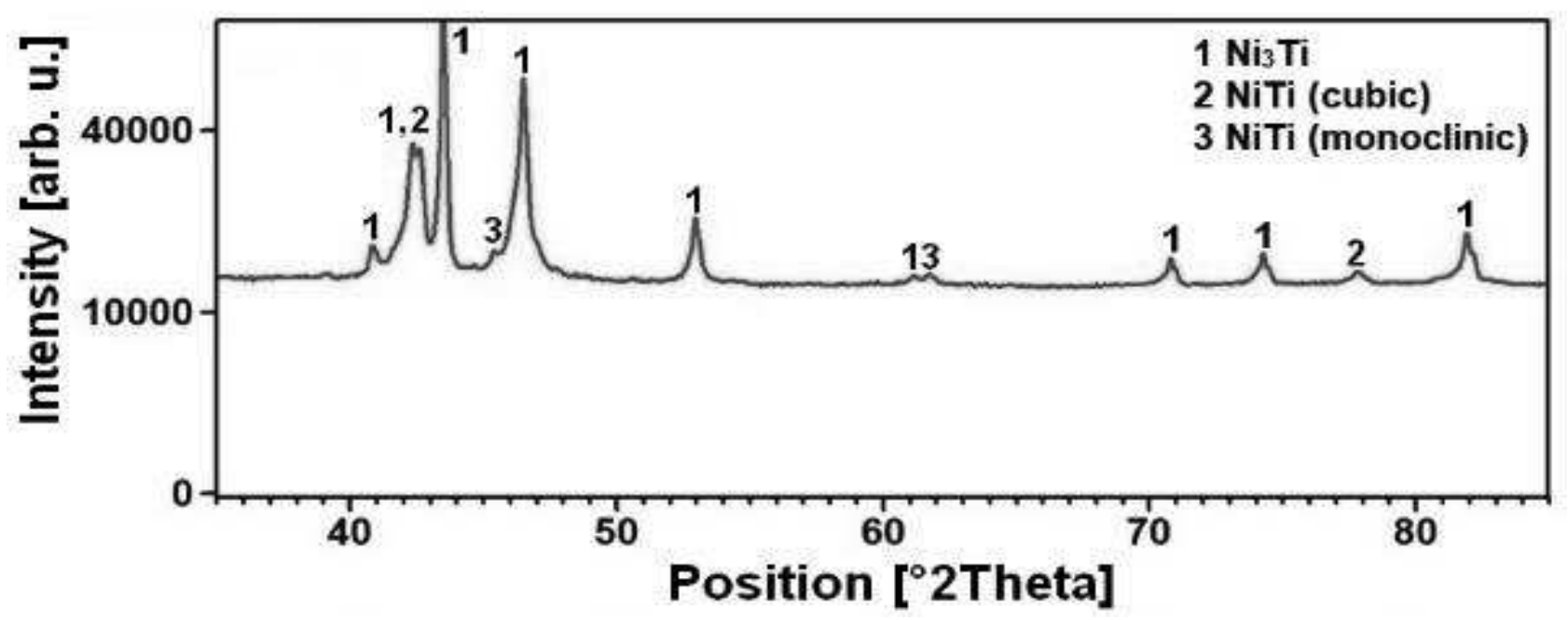

Fig. 6 XRD pattern of the Ni-Ti30 wt. \% alloy
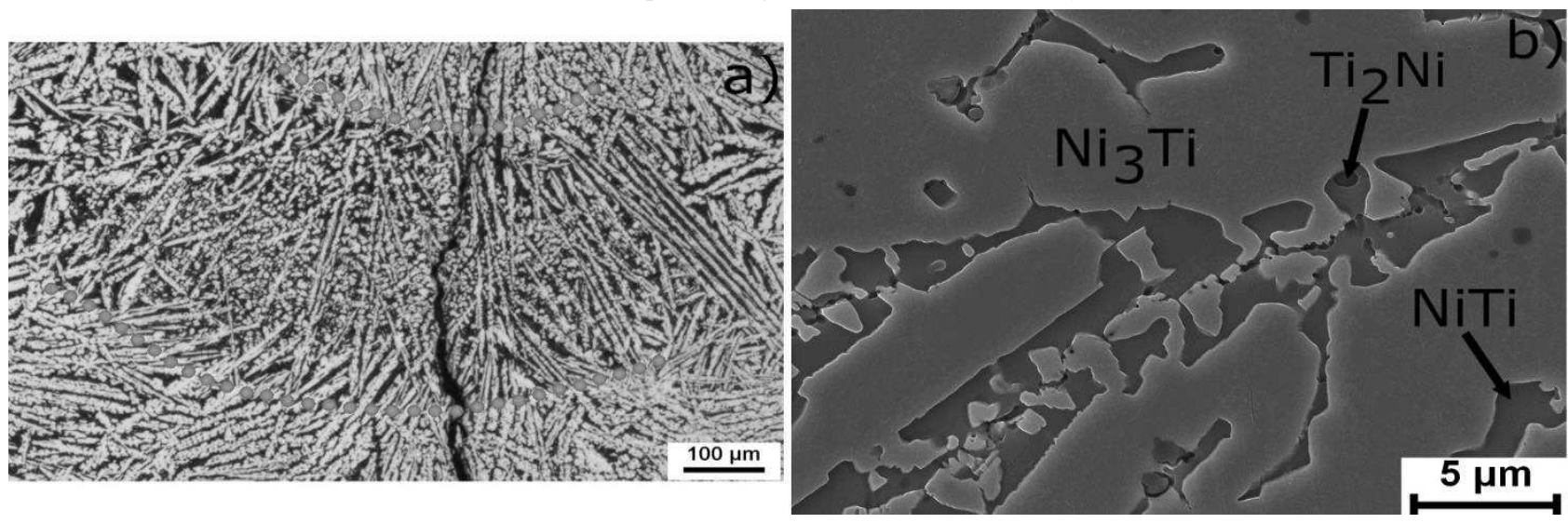

Fig. 7 Microstrostructure of Ni-Ti30 wt. \% a) melt pools and crack - light microscope, b) individual phases by SEM

Tab. 2 Chemical composition of phases in Ni-Ti30 alloy

\begin{tabular}{ccc}
\hline Phase & Ni (wt. \%) & Ti (wt. \%) \\
\hline $\mathrm{Ni}_{3} \mathrm{Ti}$ & 74.8 & 25.2 \\
$\mathrm{NiTi}$ & 55.4 & 44.6 \\
$\mathrm{Ti}_{2} \mathrm{Ni}$ & 39.4 & 60.6 \\
\hline
\end{tabular}

\section{Conclusions}

The study provided an investigation of formation of the Ni-Ti intermetallic phases during additive manufacturing - direct energy deposition. The research was conducted by preparation of two model samples. The first one contained the titatanium layer deposited on the nickel layer. The sample cracked between both layers across the whole sample mainly along the $\mathrm{Ti}_{2} \mathrm{Ni}$ phase and the $\mathrm{Ti}_{2} \mathrm{Ni} / \mathrm{NiTi}$ interface. Nevertheless at both sides of crack there were formed intermetallic phases - the titanium rich side is composed by the $\mathrm{Ti}_{2} \mathrm{Ni}$ phase in which the fraction of titanium increases gradually. The nickel rich side starts with the $\mathrm{Ti}_{2} \mathrm{Ni}$ phase or NiTi phase with inclusions of the $\mathrm{Ti}_{2} \mathrm{Ni}$ phase. The $\mathrm{Ni}_{3} \mathrm{Ti}$ phase was formed in the NiTi phase with inceasing content of nickel. Pure nickel and titanium are at the edges of the sample. In case of the deposition $\mathrm{Ni} / \mathrm{Ti} / \mathrm{Ni} / \mathrm{Ti}$... layers with thickness of $1 \mathrm{~mm}$, the areas of pure titanium and nickel disappeared. The microstructure consisted of the $\mathrm{Ni}_{3} \mathrm{Ti}, \mathrm{Ni}_{4} \mathrm{Ti}_{3}, \mathrm{NiTi}$ and $\mathrm{Ti}_{2} \mathrm{Ni}$ phases and contained the porosity in the $\mathrm{Ti}_{2} \mathrm{Ni}$ phase area. The preparation of the nickel rich sample (Ni-Ti26 wt. \%) showed the decrease of nickel content in the alloy about 4 wt. $\%$.

\section{Acknowledgement}

The paper was supported from ERDF Pre-Application Research of Functionally Graduated Materials by Additive Technologies, No. CZ.02.1.01/0.0/0.0/17_048/0007350 and from specific university research MSMT 21-SVV/2019.

\section{References}

[1] NARESH, C., BOSE, P. S. C., RAO, C. S. P. (2016). Shape memory alloys: a state of art review. In: IOP Conference Series: Materials Science and Engineering, Vol. 149, No. 1, pp. 012054.

[2] NAYAN, N., GOVIND, SAIKRISHNA, C. N., RAMAIAH, K. V., BHAUMIK, S. K., NAIR, K. S., MITTAL, M. C. (2007). Vacuum induction 
melting of NiTi shape memory alloys in graphite crucible. In: Materials Science and Engineering: A, Vol. 465, No. 1, pp. 44-48.

[3] CHUPRINA, V. G., SHALYA, I. M. (2002). Reactions of TiNi with Oxygen. In: Powder Metallurgy and Metal Ceramics, Vol. 41, No. 1, pp. 85-89.

[4] KAI, W.-Y., CHANG, K.-C., WU, H.-F., CHEN, S.-W., YEH, A.-C. (2019). Formation mechanism of Ni2Ti4Ox in NITI shape memory alloy. In: $M a$ terialia, Vol. 5, pp. 100194.

[5] DUERIG, T., PELTON, A., TREPANIER, CH. (2011). Nitinol - PART I Mechanism and Behaviour, In: SMST e-Elastic newsletter, ASM International.

[6] KRIŠTOFOVÁ, P., KUBÁSEK, J., VOJTĚCH, D., PALOUŠEK, D., SUCHÝ, J. (2019). Microstructure of the Mg-4Y-3RE-Zr (WE43) magnesium alloy produced by 3D Printing. In: Manufacturing Technology, Vol. 19, No. 1, pp. 89-94.

[7] KOUKOLIKOVA, M., PODANY, P., MERTOVA, K. (2019). Comparison of the powder bed fused materials from different powder manufacturers. In: MM Science Journal, Vol. 2019, pp. 2772-2777.

[8] DZUGAN, J., SEIFI, M., PROCHAZKA, R., RUND, M., PODANY, P., KONOPIK, P., LEWANDOWSKI, J. J. (2018). Effects of thickness and orientation on the small scale fracture behaviour of additively manufactured Ti-6Al-4V. In: Materials Characterization, Vol. 143, pp. 94109.

[9] HUMBEECK, J. V. (2018). Additive Manufacturing of Shape Memory Alloys. In: Shape Memory and Superelasticity, Vol. 4, No. 2, pp. 309-312.

[10] FOUSOVA, M., VALESOVA, V., VOJTECH, D. (2019). Corrosion of 3D-printed ALSI9Cu3Fe Alloy. In: Manufacturing Technology, Vol. 19, No. 1, pp. 29-36.

[11] YUAN, B., ZHU, M., CHUNG, C. Y. (2018). Biomedical Porous Shape Memory Alloys for HardTissue Replacement Materials. In: Materials, Vol. 11, No. 9, pp. 1716.

[12] ELAHINIA, M. H., HASHEMI, M., TABESH, M., BHADURI, S. B. (2012). Manufacturing and processing of NiTi implants: A review. In: Progress in Materials Science, Vol. 57, No. 5, pp. 911-946.

[13] KRISTIANOVÁ, E., NOVÁK, P. (2015). Properties, production and applications of NiTi shape memory alloy. In: Manufacturing Technology, Vol. 15, No. 6, pp. 995-998.
[14] KUČERA, V., ČAPEK, J., MICHALCOVÁ, A., VOJTĚCH, D. (2014). Preparation and characterization of niti shape memory alloy preparedby powder metallurgy. In: Manufacturing Technology, Vol. 14, No. 3, pp. 342-347.

[15] ELAHINIA, M., SHAYESTEH MOGHADDAM, N., TAHERI ANDANI, M., AMERINATANZI, A., BIMBER, B. A., HAMILTON, R. F. (2016). Fabrication of NiTi through additive manufacturing: A review. In: Progress in Materials Science, Vol. 83, pp. 630-663.

[16] HAMILTON, R. F., PALMER, T. A., BIMBER, B. A. (2015). Spatial characterization of the thermal-induced phase transformation throughout asdeposited additive manufactured NiTi bulk builds. In: Scripta Materialia, Vol. 101, pp. 56-59.

[17] FRAZIER, W. E. (2014). Metal Additive Manufacturing: A Review. In: Journal of Materials Engineering and Perfomance, Vol. 23, No. 6, pp. 1917-1928.

[18] GU, D.; MA, C. (2018). In-situ formation of Ni4Ti3 precipitate and its effect on pseudoelasticity in selective laser melting additive manufactured NiTi-based composites. In: Applied Surface Science, Vol. 441, pp. 862-870.

[19] WHITNEY, M., CORBIN, S. F., GORBET, R. B. (2008). Investigation of the mechanisms of reactive sintering and combustion synthesis of $\mathrm{NiTi}$ using differential scanning calorimetry and microstructural analysis. In: Acta Materialia, Vol. 56, No. 3, pp. 559-570.

[20] WHITNEY, M., CORBIN, S. F., GORBET, R. B. (2009). Investigation of the influence of $\mathrm{Ni}$ powder size on microstructural evolution and the thermal explosion combustion synthesis of NiTi. In: Intermetallics, Vol. 17, No. 11, pp. 894-906.

[21] BASTIN, G. F., RIECK, G. D. (1974). Diffusion in the titanium-nickel system: I. occurrence and growth of the various intermetallic compounds. In: Metallurgical Transactions, Vol. 5, No. 8, pp. 1817-1826.

[22] NOVÁK, P., POKORNÝ, P., VOJTĚCH, V., KNAISLOVÁ, A., ŠKOLÁKOVÁ, A., ČAPEK, J., KARLÍK, M., KOPEČEK, J. (2015). Formation of Ni-Ti intermetallics during reactive sintering at $500-650{ }^{\circ} \mathrm{C}$. In: Materials Chemistry and Physics, Vol. 155, pp. 113-121.

[23] HALANI, P. R., SHIN, Y. C. (2012). In Situ Synthesis and Characterization of Shape Memory Alloy Nitinol by Laser Direct Deposition. In: $M e$ tallurgical and Materials Transactions A, Vol. 43, No. 2, pp. 650-657.

[24] KRISTIANOVÁ, E., NOVÁK, P. (2016). Composite materials NiTi-Ti2Ni. In: Manufacturing Technology, Vol. 16, No. 5, pp. 961-965. 